\title{
LAMPU HIAS DENGAN DEKORASI MOTIF BATIK PARANG DAN KAWUNG INOVASI PENCIPTAAN KERAMIK
}

\author{
Dwita Anja Asmara ${ }^{1)}$ \\ ${ }^{1}$ Fakultas Seni Rupa, Institut Seni Indonesia Yogyakarta \\ email: dwita.anja@gmail.com \\ Sarasati Meilani²) \\ ${ }^{2}$ Fakultas Seni Rupa, Institut Seni Indonesia Yogyakarta \\ email: sarascell868686@gmail.com
}

\begin{abstract}
Product innovation is a strategy that must be carried out by(UMKM) in the craft business in order to always have a competitive advantage. This research is a discussion to get ceramic products that have an assessment of Indonesia so that they can compete in the global market. Parang and Kawung traditional batik motifs representing the freedom of choice of Indonesia were chosen as a form of innovation that was tried to be mixed with ceramic decorative lighting products. This batik motif is not only placed on ceramic decorative lighting products, but will be made together and become a part or character of the ceramics. This study uses a renewal method in the design of ceramic products, starting from the exploration of trends, analysis, sketching, and the last is per work design drawings or designs. Embodiment or production is done by experimentation to get the right material composition, technique, and production method or process. It will also conduct a market test by exhibiting prototype products in art-shops owned by ceramic craftsmen. The research target in the first year is the creation of techniques or production methods, and 10 ceramic designs that are in accordance with market trends and tastes. In the second year the creation of 10 prototype products and submitted to IPR, approved scientific articles, and market testing. The results of this study are expected to help craftsmen diversify their products to increase sales for the export market.
\end{abstract}

Keywords: ceramics, innovation, batik motifs

\begin{abstract}
ABSTRAK
Inovasi produk adalah strategi yang harus terus dilakukan oleh usaha mikro kecil menengah (UMKM) kerajinan agar selalu memiliki keunggulan kompetitif. Penelitian ini adalah sebuah eksplorasi penciptaan untuk mendapatkan produk keramik yang memiliki nuansa etnis Indonesia sehingga dapat berkompetisi pada pasar global. Motif batik tradisional Parang dan Kawung mewakili nuansa etnis Indonesia dipilih sebagai bentuk inovasi yang dicoba untuk di-mix-kan dengan produk lampu hias keramik. Motif batik tersebut tidak hanya sekedar ditempelkan pada produk lampu hias keramik, akan tetapi dibuat menyatu dan menjadi bagian atau karakter dari keramik tersebut. Penelitian ini menggunakan metode pendekatan estetis dalam merancang desain produk keramik, dimulai dari ekplorasi trend, analisis, pembuatan sketsa, serta yang terakhir adalah perancangan gambar kerja atau desain. Perwujudan atau produksi dilakukan dengan eksperimentasi untuk mendapatkan komposisi bahan, teknik, dan metode atau proses produksi yang tepat. Selain itu juga akan dilakukan uji pasar (market test) dengan memamerkan produk prototype di art-shop yang dimiliki oleh pengrajin keramik. Target penelitian pada tahun pertama adalah terciptanya teknik atau metode produksi, dan 10 desain keramik yang sesuai dengan trend dan selera pasar. Pada tahun ke dua terciptanya 10 produk prototype dan mendaftarkan ke HKI, penerbitan artikel ilmiah, serta uji pasar. Hasil penelitian tersebut
\end{abstract}


diharapkan dapat membantu para pengrajin melakukan diversifikasi produk guna meningkatkan penjualan terutama untuk pasar ekspor.

Kata Kunci: keramik, inovasi, motif batik

\section{PENDAHULUAN}

Inovasi merupakan bagian yang penting bagi usaha mikro kecil menengah (UMKM), karena tanpa inovasi produk yang di buat jelas akan tertingal dari lajunya perputaran ide dan kreatifitas, karena inovasi dapat menjadi keunggulan kompetitif bagi UMKM dalam menghadapi persaingan. Untuk strategi inovasi dapat lakukan dengan dua bentuk pekerjaan yaitu inovasi produk dan inovasi proses, agar pengembangan usaha mikro kecil menegah lebih kuat dalam berinovasi kedalam dilakukan yaitu; inovasi produk, inovasi proses, inovasi pelayanan, inovasi pasar, inovasi logistik, dan inovasi organisasional. Inovasi proses yang dimaksud sebagai perubahan yang dilakukan dalam proses produksi yang ditujukan untuk meningkatkan kapasitas produksi dan produktivitas tenaga kerja. Sedangkan inovasi produk lebih mengarah pada penciptaan produk baru dengan tampilan dan atau kualitas yang lebih baik sehingga akan lebih menguntungkan dibandingkan dengan produk yang terdahulu. Dua jenis tindakan inovasi ini akan menjadikan usaha mikro kecil menengah akan lebih berkembang, terkain dengan kasus ini adalah kerajinan keramik.

UMKM kerajinan keramik, salah satunya di sentra gerabah Kasongan, Bantul, DIY, beberapa waktu ini mengalami kelesuan penjualan ekspor akibat terjadinya krisis yang melanda negara-negara Eropa terutama Yunani. Selama ini pasar utama ekspor produk-produk kerajinan keramik adalah di Amerika dan Eropa. Selain itu, persaingan produk kerajinan keramik juga semakin kompetitif, terutama persaingan dengan produsen keramik dari negara lain seperti Vietnam dan Cina. Oleh karena itu, UMKM kerajinan keramik harus terus melakukan inovasi agar dapat bertahan dalam persaingan dan meningkatkan kembali ekspor produknya. Melahirkan sebuah inovasi pada produk, dengan mencoba menciptakan produk baru, tampilan dan gaya (style) baru, teknik kombinasi, menarik dan berkwalitas.

Persoalannya saaat ini pengerajin terlalu terpaku pada satu jenis produk, yang sehaarusnya dilakukan diversivikasi untuk menghindari produk tunggal beredar dan dapat mencegah monopoli produk dll. Diversifikasi atau inovasi pengembangan produk merupakan sesuatu yang harus segera dipecahkan. Penciptan ini berusaha untuk melakukan penciptakan produk baru dalam bentuk lampu hias kerajinan keramik sebagai bagian dari strategi inovasi produk. Inovasi yang dicoba akan dilakukan adalah dengan menciptakan desain lampu hias keramik dengan penerapan dekorasi motif batik tradisional Parang dan Kawung. Pilihan ini dilakukan mengingat saat ini batik sudah dikenal oleh dunia dan diakui oleh UNESCO sebagai warisan budaya tak benda sejak tanggal 2 Oktober 2009. Bahkan tanggal tersebut kemudian ditetapkan oleh pemerintah menjadi hari batik nasional. Batik Indonesia menjadi ikon budaya bangsa yang memiliki nilai etnik, keunikan, simbol serta filosofi yang mendalam. Nilai etnik dan lokalitas seni budaya inilah yang perlu dikembangkan, terutama untuk produk-produk kerajinan. Produk kerajinan biasanya dipilih oleh konsumen karena memiliki kekhasan dengan wilayah dimana produk tersebut dibuat. Produk kerajinan keramik bermotif batik ini diharapkan dapat diterima oleh konsumen yang 
menginginkan produk yang memiliki keunikan dan nilai etnik budaya lokal. Produk hias keramik dengan mengambil ide motif kawung dan parang ini, menciptakan sebuah inovasi pengabungan berapa teknik, yaitu teknik keramik berglasir glasirnya, mengambangkan style pada keramik dengan paduan teknik ukir logam dan menerapkan teknik batik di badan keramik. Penelitian ini membahas bagaimana proses perwujudan produk lampu hias dengan mengaplikasikan motif batik Parang dan Kawung, beserta style yang dikembangkan pada produk lampu hias. Harapkan dalam pembuatan produk ini, menghasilkan produk lampu hias keramik dengan bentuk, style dan karakter seni kerajinan keramik khas Indonesia yang inovatif dengan mengangkat motif batik tradisional. Memperkaya referensi inovasi produk keramik yang lebih bervariatif. Produk seni kerajinan keramik saat ini mengalami penurunan akibat krisis global, sehingga dengan adanya produk baru menjadi alternatif pilihan bagi para pembeli. Oleh karena itu perlu memperbanyak variasi baru guna menangkap pasar ekspor. Meningkatkan nilai ekonomi seni kerajinan keramik untuk dapat diterima di pasar ekspor, sehingga ekonomi masyarakat pengrajin seni kerajinan keramik memperoleh peningkatan.

\section{METODE}

Penelitian ini dilakukan untuk menghasilkan inovasi produk lampu hias keramik dengan dekorasi motif batik Parang dan Kawung, menggunakan metode pendekatan estetis dan ekonomis. Pendekatan estetis digunakan untuk melakukan proses eksplorasi mencari bentuk, warna dan karakter yang unik, kreatif-inovatif, dan memiliki lokalitas seni budaya. Sedangkan pendekatan ekonomis adalah untuk menilai sejauh mana kemampuan produk itu dalam memberikan dampak ekonomi pada masyarakat pengrajin.

Metode penciptaan lampu hias keramik ini menggukan pendekatan practice-based research, ialah metode atau cara teknik serta alat khusus bagi peneliti yang berbasis praktik dalam bentuk tulisan karya ilmiah yang dipublikasikan dari hasil jenis penelitian berbasis praktik seperti bidang seni, desain, film, dan sastra (Hendriyana, 2008). Penciptaan sebuah karya memiliki ciri yang berfokus pada proses, mengacu pada objek riset. Menurut Gray dan Malins, penelitian di bidang seni memiliki karakteristik menggunakan banyak pendekatan dan beragam metode yang disesuaikan dengan penelitian karya seni yang dibuat oleh setiap individu (Gray, Carole, 2004).

Studi pustaka dan observasi untuk pengumpulan data dan informasi yang diperlukan sesuai dengan masalah penelitian, yakni masalah inovasi desain lampu hias keramik yang sesuai dengan trend yang sedang berkembang, potensi ketrampilan membuat keramik dan inovasi motif batik sebagai nilai tambah untuk memberikan nuansa etnis.

Data yang sudah diperoleh dan dianalisis selanjutnya dilakukan perancangan dengan melakukan pembuatan sketsa-sketsa alternatif. Beberapa sketsa yang dinilai sesuai dengan tujuan penelitian kemudian dipilih untuk dibuat desain atau gambar kerja. Sehingga akan memudahkan dalam pelaksanaan perwujudan atau produksi produk 10 sepuluh lampu hias keramik.

Perwujudan adalah proses memvisualisasikan ide-konsep yang telah dibuat desain atau gambar kerja. Melalui eksplorasi dan eksperimentasi dilakukan penentuan bentuk, warna serta finishing produk. Tahapan dari proses pembentukan adalah persiapan bahan, persiapan alat, 
pembentukan, pengeringan, pembakaran, dan finishing. Produk lampu hias keramik yang diwujudkan dikombinasikan dengan bahan lain seperti, logam dan kayu sebagai inovasi produk.

Penelitian ini menggunakan beberapa referensi yang dapat membantu dalam memahami lebih mendalam tentang objek penelitian. Referensi tersebut adalah dari penelitian-penelitian yang pernah dilakukan, buku keramik dan batik yang mendukung proses kreatif dalam menciptakan produk keramik.

Penelitian terdahulu Arif Suharson dan Dwita Anja Asmara tentang Komposisi Tanah untuk Teknik Reproduksi di Sentra Gerabah Pagerjurang, Klaten, Jawa Tengah. Penelitian tanah liat earthenware Bayat sebagai bahan baku pembuatan keramik. Tinjauan ini sangat relevan dan penciptaan ini menggunakan beberapa referensi yang dapat membantu dalam memahami lebih mendalam tentang objek penelitian (Suharson, Arif., 2011).

Penelitian lain yang dilakukan oleh Dwita Anja Asmara dan Joko Subiharto, tentang Penciptaan Seni Kerajinan Keramik Inovasi Motif Batik Parang dan Kawung Sebagai Pengembangan Industri Kreatif Berbasis Seni Budaya Lokal. Penelitian ini dilakukan hingga eksperimentasi untuk mendapatkan komposisi bahan glasir dan teknik penciptaan yang sesuai dengan hasil percobaan glasirnya (A, A. Dwita., dan Subiharto, 2015).

Keramik Bahan Cara Pengerjaan Glasir yang ditulis oleh Ambar Astuti (Astuti, 2008a), menjelaskan tentang pengetahuan bahan baku dan bantu dalam keramik. Buku lain yang masih dengan pengarang yang sama berjudul Keramik Ilmu dan Proses Pembuatannya, menjelaskan tentang hal-hal yang berkaitan dengan keramik, teknik pembuatan keramik, dan berbagai macam bentuk dekorasi pada keramik (Astuti, 2008b).
Buku berjudul Ceramics for the Artist Potter yang ditulis FH Norton, sebuah buku lama namun isinya masih relevan. Bagian "Aplication of Design Theory to Pottery", sangat bermanfaat untuk analisis desain. Buku edisi yang kedua diterbitkan oleh Addison Wesley Publishing Company,Inc, USA, tahun 1956.

Kamus Keramik, ditulis oleh Brian Alexander, dengan penerbit Milenia Populer, Jakarta, 2001. Buku ini membahas tentang petunjuk praktis dalam mengetahui bahanbahan keramik yang sudah diterjemahkan dalam bahasa Indonesia dan bahasa Inggris. Buku ini dapat dipakai sebagai dasar dari suatu percobaan glasir yang nantinya akan di terapkan pada produk keramik.

Buku tentang proses penciptaan oleh Peter Domer tentang The New Cramics Trend+Traditions, membahas tentang perkembangan keramik terutama keramik contemporary yang berkembang di Amerika dan dunia bagian Barat. Buku tersebut juga membahas tentang perkembangan bentuk, pewarnaan keramik, dan model diluar kebiasaan (Domer, 1994, pp. 1-132).

Karya Timbul Raharjo berjudul Teko dalam Perspektif Seni Keramik, sebuah buku yang dapat dijadikan acuan mngenai bagaimana menciptakan seni kerajinan keramik dengan pertimbangan teknologi dan bahan tanah liatnya. Tata urutan perwujudan diantaranya, penentuan tema terpilih, identifikasi masalah dan produk, eksplorasi, eksperimen, dan pembentukan (Raharjo, 2011).

Buku The Decorative Touchkarya oleh Carl E. Paak (1981), buku ini banyak menyajikan finishing touch untuk produk stoneware dan porselin. Buku ini banyak menyajikan teknik finishing dengan gores, inlay, engobe dan glasir, yang terdiri dari dekorasi Greenware, dekorasi Bisqueware, dan Glazed color. 
Penelitian ini akan menghasilkan sebuah penemuan baru yang akan diuji cobakan pada pasar, maka perlu penambahan pustaka yang terkait dengan dunia bisnis seni kerajinan komoditi ekspor. Buku tentang ekspor impor karangan Amir MS, menjelaskan kedudukan komoditi kita, pengendalian harga, kemajuan teknologi informasi, hambatan eksport non migas, peningkatan daya saing, kendala dan fasilitas (MS, 2005).

Buku batik yang dijadikan rujukan dalam penelitian ini diantaranya adalah buku yang ditulis oleh Sewan Susanto dengan judul Seni Kerajinan Batik Indonesia. Buku yang mengulas secara tuntas tentang batik Indonesia dalam empat bahasan utama, yaitu tinjauan tentang berbagai cara pembuatan batik, masalah bahan-bahan batik dan zat warna batik, pembahasan tentang masalah batik/analisis khusus tentang seni batik, dan sejarah perkembangan seni batik (Susanto, 1973).

Buku yang berjudul Batik dan Mitra yang ditulis oleh Nian S.Djomena, mengungkapkan beberapa aspek seputar tentang batik yang dikaji dari sisi kekhasan serta perkembangannya. Beberapa jenis kain batik dan makna simbolis motif batik diungkap secara jelas (Djomena, 1990).

\section{HASIL DAN PEMBAHASAN}

\section{Motif Parang dan Kawung}

Batik Motif parang merupakan baju kebesaran keraton di Jawa, terutama Yogyakarta dan Surakarta dan yang boleh memakai adalah Raja, Permaisuri dan putranya. Kata parang berasal dari kata pereng, yang dalam bahasa Jawa berarti pinggiran suatu tebing yang berbentuk pereng yang menghubungkan antara dataran tinggi dengan dataran rendah yang membentuk garis diagonal (Kusrianto, 2013). Istilah ini di ilhami dasar gambaran tebing di pesisir pantai selatan pulau Jawa. di daerah tersebut banyak didapati nama seperti Paranggupito, Parangkusumo, Parangtritis dan sebagainya. Motif Parang merupakan salah satu motif yang banyak sekali variannya, ada sekitar 68 motif batik parang (Kusrianto, 2013). Berikut ini beberapa motif batik parang yang terkenal, motif Parang Rusak, motif Parang Barong, motif Parang Rusak Barong,

Selain motif Parang yang sangat populer dan memiliki variasi sangat beragam, motif lain yang tidak kalah populer dan memiliki variasi yang banyak adalah batik motif Kawung. Bentuk motif Kawung sebenarnya merupakan salah satu bentuk ornamen yang sangat kuno dan telah ada berabad-abad yang lalu. Sedangkan batik motif kawung diyakini diciptakan oleh Sultan Mataram, dan merupakan salah satu dari motif larangan seperti halnya motif Parang. Ornamennya disarikan dari buah pohon aren, atau kolang-kaling yang kemudian didistorsikan dalam bentuk oval dan disusun silang, menggambarkan struktur jagad raya. Pusat persilangannya merupakan sumber energi dan miniatur jagad raya (Kusrianto, 2013).

Simbolisme lain yang terdapat pada motif ini adalah dikaitkan dengan falsafah Jawa "Sadulur papat limo pancer" yang kurang lebih melambangkan persaudaraan yang berjumlah empat menghadap pada satu titik di tengah yang dianggap sebagai pusat kekuatan alam semesta. Pendapat umum juga sering mengkaitkan dengan kepemimpinan Raja merupakan inti atau pusat kekuatan alam semesta, pemimpin 
manusia, pelindung yang lemah dan benar, serta wakil Tuhan di muka bumi.

Seperti halnya motif Parang, motif Kawung juga memiliki varian atau turunan yang cukup banyak. Biasanya motif-motif Kawung diberi nama berdasarkan besarkecilnya bentuk bulat-lonjong yang terdapat dalam suatu motif tertentu. Misalnya motif Kawung Picis adalah motif kawung yang tersusun oleh bentuk bulatan yang berukuran kecil. Sedangkan Kawung Bribil adalah motif-motif kawung yang tersusun oleh bentuk lebih besar daripada Kawung Picis.

Saat ini penerapan motif Parang dan Kawung pada berbagai produk setelah batik Indonesia diakui oleh UNESCO sebagai warisan budaya tak benda, batik langsung mengalami booming atau peningkatan produksi dan penjualan. Sentra-sentra batik seperti di Yogyakarta dan Solo mulai bergeliat setelah lama mati suri. Produksi batik mengalami peningkatan yang sangat pesat dikarenakan permintaan dari berbagai daerah mulai berdatangan. Desain-desain baru juga bermunculan seiring dengan meningkatnya permintaan masyarakat akan batik. Pemerintah, sekolah-sekolah dan lembaga-lembaga lain mewajibkan anggotanya untuk mengenakan pakaian batik pada hari-hari tertentu. Semua hal tersebut menjadi pemicu batik menjadi bagian dari budaya masyarakat Indonesia yang dibanggakan saat ini.

Perkembangaan saat ini, batik terutama motifnya banyak digunakan atau diterapkan sebagai dekorasi berbagai macam produk. Motif batik yang memiliki ciri etnik atau memiliki ke khasan budaya Indonesia digunakan untuk membuatproduk-produk yang bertemakan etnik baik untuk keperluan elemen interior seeprti lampu hias, aksesoris, keperluan rumah tangga dan lain-lain. Sentuhan etnik dengan menggunakan motif batik saat ini di pasaran cukup banyak jumlahnya, dan memiliki segmentasi pasar tertentu.

\section{Pembentukan Produk Lampu Hias Keramik}

Proses ini diawali dengan mengidentifikasi kain batik yang bermotif kawung dan parang meliputi bentuk, warna dan sketsa dasar motif selanjutnya mengklasifikasikannya untuk dilakukan pengembangan dan pembuat desain ornamen motif batik kawung dan parang. Beberapa rancangan ornamen yang telah tercipta selanjutnya dipilih menjadi disain yang akan di terapakan pada keramik. Selanjutkan masuk ke tahap pembentukan produk Lampu Hias Keramiik meliputi

1. Tahap Pengolahan Bahan: Pengolahan bahan dilakukan dengan pengolahan secara basah, dengan cara: perendaman, pengentalan, pengulian, dan penimpanan.

2. Tahap Persiapan Alat
a. Slab roller, alat untuk membuat lempengan tanah liat.
b. Pisau, untuk memotong lempengan tanah liat.
c. Penggaris, unyuk mengukur lempengan tanah liat.
d. Jarum dan butsir, untuk membuat dekorasi pada body lampu.
e. Tungku pembakaran, digunakan untuk membakar pada tahap pembakaran biskuit dan pembakaran glasir.

f. Kuas, untuk penerapan glasir pada keramik yang sudah dibakar biskuit.

3. Tahap Pembentukan dengan Teknik Slab/ Lempeng

Teknik lempeng ialah pembentukan keramik dengan cara membuat lempengan tanah liat dengan ketebalan yang sama menggunakan slab roller. Hasil lempengan 
tanah dibentuk sesuai dengan desain lampu hias lalu diterapkan dekorasi. Teknik dekorasi yang digunakan berupa teknik dekorasi ukir (carving) yaitu, dekorasi keramik dalam keadaan tanah liat sedikit menggeras yang diukir menggunakan alat pisau dan butsir. Hasil dekorasi pada lampu hias berupa motif Parang dan Kawung.

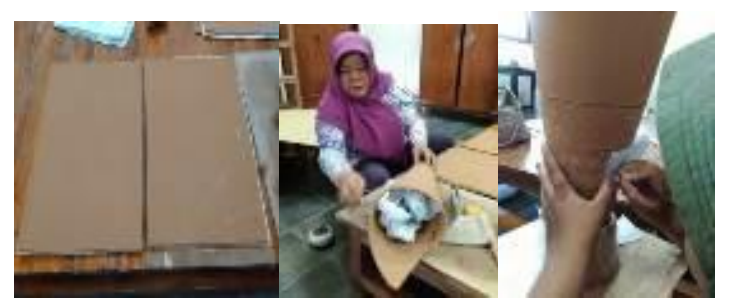

Gambar 1. Pembentukan teknik lempeng lampu hias keramik. (Foto oleh Sarasati Meilani, 2019)

4. Tahap Pembentukan dengan Teknik Cetak Tuang

Langkah pertama yang dilakukan ialah membuat model cetakan menggunakan tanah model. Model disarankan agar padat atau tidak berongga, agar tidak terjadi perubahan bentuk dan bodynya kuat. Hal yang perlu dihidari dalam pembuatan model cetakan agar tidak membuat bentuk-bentuk yang runcing dan rumit.

Dekorasi dengan mengukir motif Parang dan Kawung pada bodi lampu menggunakan alat pisau dan butsir. Membuat cetakan lampu hias keramik. Bahan utama yang digunakan dalam membuat cetakan model ialah gypsum. Gypsum dipilih karena sifatnya yang mampu menyerap air dan mudah untuk dibuat cetakan. Alat yang dibutuhkan antaralain: kuas, sabun deterjen (sebagai pelumas atau pelicin), seng, tanah model, dan gunting besi.

Cetak tuang atau disebut bodi tuang yaitu suatu larutan tanah liat yang dicampur dengan bahan tertentu. Larutan ini dapat dituang ke dalam cetakan gips. Mengisi cetakan, prinsip pada teknik ini adalah slip (larutan tanah liat yang tidak terlalu encer) dituangkan ke dalam cetakan gips. kulit tanah ini sudah cukup tebalnya, larutan sisanya dituangkan kembali dan kulit yang tinggal dibiarkan kering dan menyusut. Setelah menyusut akan terlepas dari cetakan gips dan hasil cetakan dapat dikeluarkan.
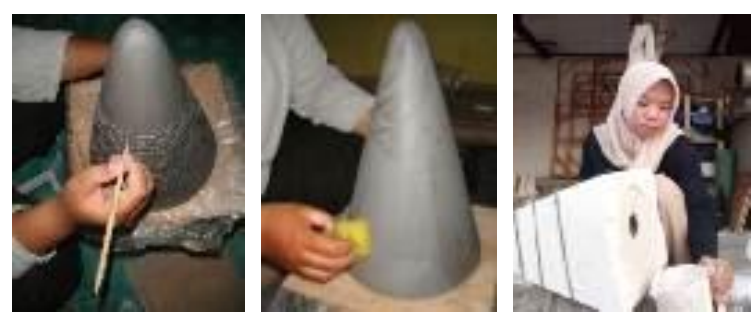

Gambar 2. Tahap pembentukan teknik cetak tuang lampu hias keramik. (Foto oleh Dwita Anja Asmara, 2019)

\section{Tahap Pengeringan}

Proses pengeringan dilakukan dengan cara mengangin-anginkan hasil cetakan yang selesai dibuat di ruang terbuka, namun terhidar dari paparan sinar matahari secara langsung. Hal ini untuk menghindari proses pengeringan yang terlalu cepat yang dapat menyebabkan keretakan pada kermik.

\section{Tahap Pembakaran Biskuit}

Proses pembakaran biskuit, merupakan proses pembakaran pertama. Pembakaran biskuit dilakuakan di dalam tungku gas dengan suhu $850^{\circ} \mathrm{C}$.

7. Tahap Glasir
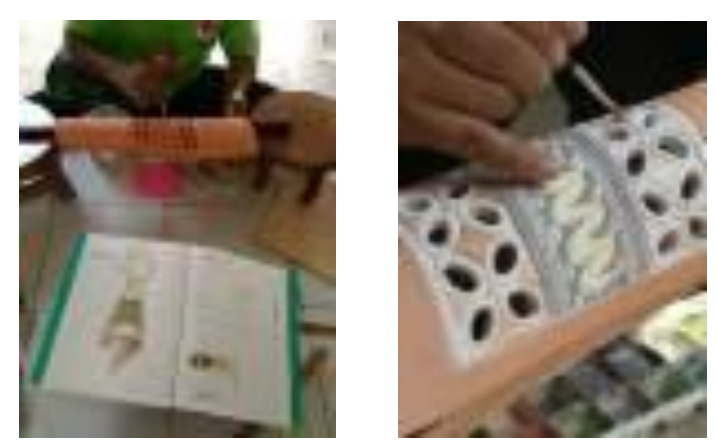

Gambar 3. Tahap glasir dengan teknik kuas pada lampu hias keramik. (Foto oleh Dwita Anja Asmara, 2019) 
Tahap glasir, merupakan proses pemberian warna pada benda keramik yang sudah dibakar biskuit. Pengglasiran ini dilakukan dengan teknik kuas. Teknik kuas dirasa tepat karena bagian motif yang akan diberi glasir kecil.

\section{Tahap Bakar Glasir}

Pembakaran glasir, merupakan pembakaran kedua dengan suhu lebih tinggi yang bertujuan melelehkan glasir yang telah diterapkan pada permukaan keramik. Pembakaran ini dilakukan di dalam tungku gas dengan suhu $1150^{\circ} \mathrm{C}$.

\section{Finishing}

a. Tahap penerapan lempengan logam

Finishing produk lampu hias keramik dengan menerapkan teknik ukir lempengan logam dan teknik batik pada badan lampu hias. Tahapan penenrapan logam dimulai dengan memindahkan pola motif batik Parang dan Kawung pada lempengan logam. Lalu, lempengan logam diukir sesuai pola di atas jabung. Hasil lempengan logam yang sudah diukir dirapikan dan diterapkan pada produk lampu hias keramik
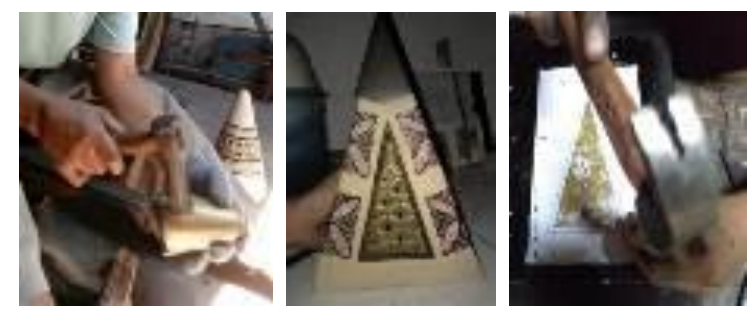

Gambar 3. Tahap penenrapan logam pada lampu hias keramik. (Foto oleh Dwita Anja Asmara, 2019)

b. Tahap membatik

Batik merupakan teknik menggambar menggunakan alat berupa canting dan bahan lilin malam panas. Tahapan batik meliputi:

10. Pemindahan pola, dilakukan dengan menggambar komposisi motif batik Parang dan Kawung sesuai desain prototype di atas body lampu hias keramik menggunakan pensil.

11. Pencantingan, yaitu menggambar komposisi motif batik Parang dan Kawung sesuai gambar pola menggunakan alat canting dan bahan lilin malam panas.

i. Penyoletan, dilakukan dengan menerapkan warna naphtol di bagian motif batik, Parang dan Kawung menggunakan kuas. Tahap mencolet harus dilakukan dengan hati-hati agar warna tidak keluar atau bleber.

ii. Pelorodan, merupakan tahap menghilangkan lilin malam dengan cara menyiramkan air panas atau merebus bagian keramik yang dibatik hingga bersih dari lilin malam. Bagian yang dicanting akan menghasilkan garis yang sesuai dengan warna tanah, sedangkan bagian yang dicolet akan menghasilkan bentuk motif yang berwarna lain.

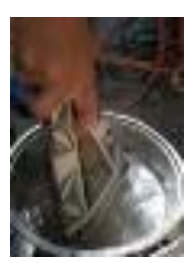

a.

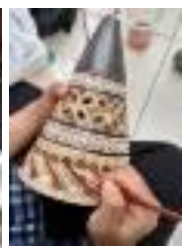

b.

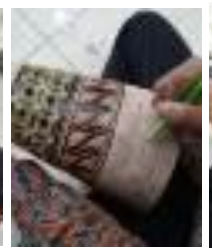

C.

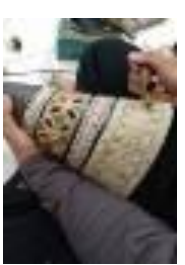

d.
Gambar 12. Tahap membatik lampu hias keramik. a. Pemindahan pola; b. Pencantingan; c. Penyoletan; d. Pelorodan. (Foto oleh Dwita Anja Asmara, 2019)

c. Tahap membubut kayu jati Beberapa produk lampu hias keramik bagian bawahnya dikombinasikan dengan kayu yang dibubut sebagai alas.

d. Tahap memasang fitting listrik. Keberhasilan dalam tahap pemasangan fitting menjadkan produk lampu hias keramik berfungsi. 


\section{IV.PENUTUP}

Menerapkan komposisi motif batik Parang dan Kawung pada media tanah liat, dengan cara mengkomposisikannya pada produk keramik. Alasan kuatnya karena motif batik Parang dan Kawung merupakan sebuah motif tradisional yang perlu dilestarikan melalui produk lampu hias keramik

Proses perwujudan produk ini cukup panjang, mulai dari menyiapkan beberapa macam bahan baku tanah liat pokok yang digunakan. Tanah liat terdiri tanah Pacitan untuk teknik slab, tanah Sukabumi untuk mengisi cetak tuang, dan tanah liat Kebumen untuk model. Pembetukan produk ini ada dua teknik, yaitu teknik cetakan tuang dan teknik slab/ lempengan. Teknik dekorasi yang digunakan untuk menerapkan motif batik Parang dan Kawung, ialah teknik gores/ diukir dan teknik krawang. Produk lampu hias ini melalui dua proses pembakaran, yaitu pembakaran biskuit dengan suhu $850^{\circ} \mathrm{C}$ dan pembakaran glasir dengan suhu $1150^{\circ} \mathrm{C}$. Sebelum produk lampu hias keramik memasuki tahap bakar glasir, dilakukan tahap pengglasiran dengan komposisi dan formula glasir yang telah di lakukan eksperimen pada penelitian sebelumnya. Penelitian ini menghasilkan 10 variasi produk lampu hias keramik dengan dekorasi motif batik Parang dan Kawung. Penelitinan ini telah mengembangkan style dengan mengkombinasikan beberapa material dan tenik penerapannya. Material yang di gunakan, seperti logam dengan teknik ukirl logam, tenik batik dengan mencanting pada bodi keramik, nyolet warna naphtol, dan melorod. Alas produk lampu hias keramik menggunakan kayu jati. Adanya inovasi ini produk lampu hias keramik fungsional memiliki nilai kreatifitas yang tinggi dan nilai lokalitas budaya.

\section{Saran}

Penciptaan produk yang akan dipasarkan baik lokal maupun nasional sebaiknya menggunakan pemahaman korelasi antara proses kreatifitas dengan membaca trend desain, pertimbangan reproduksi dan distribusi produk. Desain ini dapat diterapkan sebagai produk dalam uji coba pasar.

\section{DAFTAR PUSTAKA}

A, A. Dwita., dan Subiharto, J. (2015). Penciptaan Seni Kerajinan Keramik Inovasi Motif Batik Parang dan Kawung Sebagai Pengembangan Industri Kreatif Berbasis Seni Budaya Lokal. Yogyakarta.

Astuti, A. (2008a). Keramik Bahan Cara Pengerjaan Gelasir. Yogykarta: Arindo Nusa Media.

Astuti, A. (2008b). Keramik Ilmu dan Proses Pembuatannya. Yogykarta: Arindo Nusa Media.

Djomena, N. S. (1990). Batik dan Mitra. Jakarta: Djambatan.

Domer, P. (1994). The New Ceramics Trend+Tradition. London: Thames and Hudson Ltd.

Gray, Carole, dan J. M. (2004). No TitleVisualizing Research: A Guide to the Research Process in Art and Design. Hants dan Burlington: Ashgate Publishing Limited dan Ashgate Publishing Company.

Hendriyana, H. (2008). Metodologi Penelitian Penciptaan Karya. Bandung: Sunan Ambu Pres. 
10 ] CORAK Jurnal Seni Kriya Vol. 9 No.1, Mei-Okteber 2020

Kusrianto, A. (2013). Batik: Filosofi, Motif, dan Kegunaan. Yogyakarta: Andi.

MS, A. (2005). Ekspor Impor Teori dan Penerapannya: Seri Bisnis Internasional No. 13. Jakarta: Penerbit PPM.

Raharjo, T. (2011). Teko dalam Perspektif Seni Keramik. Bandung: Rosda.

Suharson, Arif., dan D. A. A. (2011). "Kompsisi Tanah untuk Teknik Reproduksi di Senta Gerabah Pagerjurang Klaten Jawa Tengah." Yogyakarta.

Susanto, S. (1973). Seni Kerajinan Batik Indonesia. Yogyakarta: Balai Penelitian Batik dan Kerajinan, Lembaga Penelitian Pendidikan Industri, Departeman Perindustrian RI. 
Lampiran 1. Hasil Penciptaan Lampu Hias Keramik dengan Penerapan Dekorasi Motif Batik Parang dan Kawung

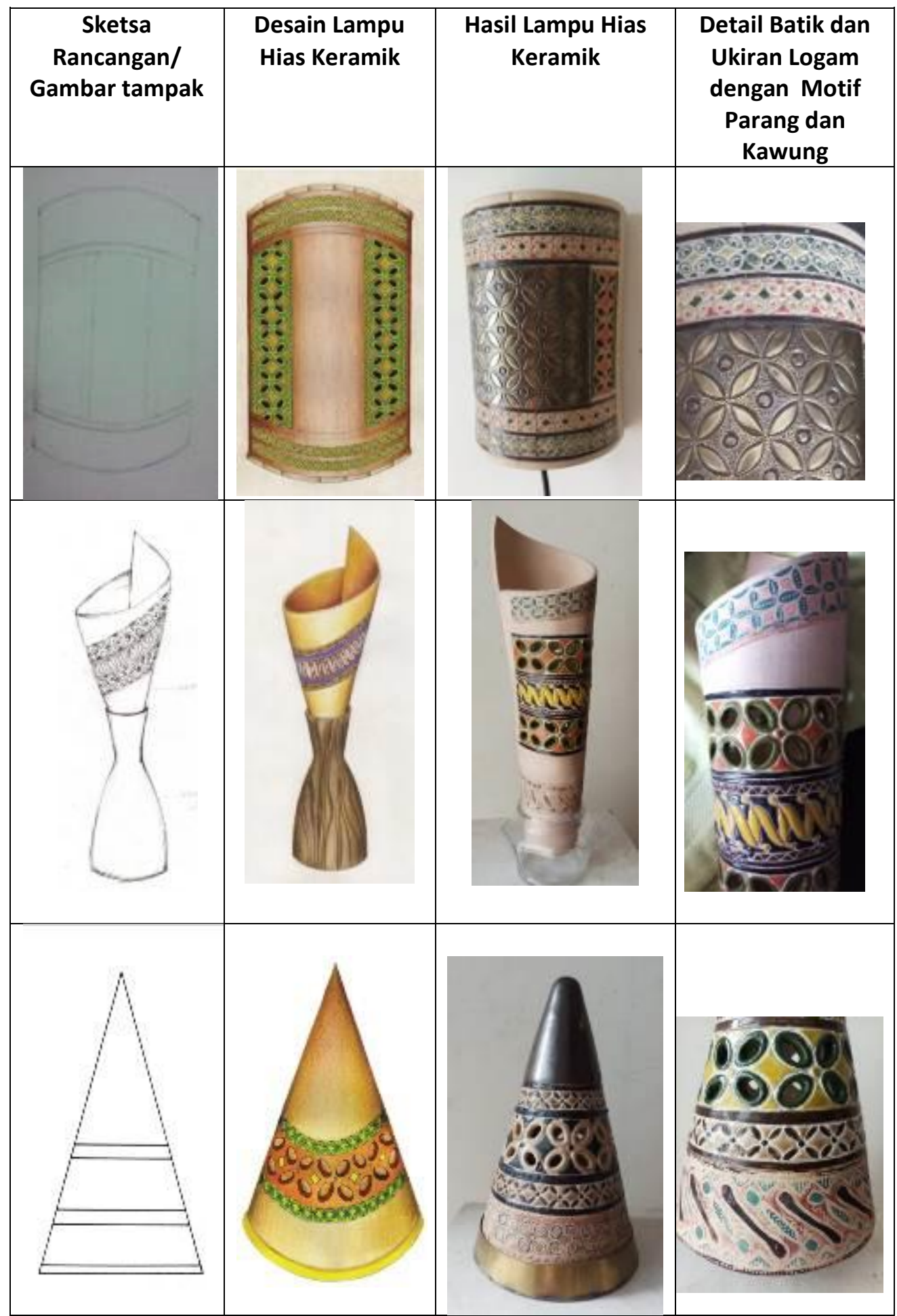




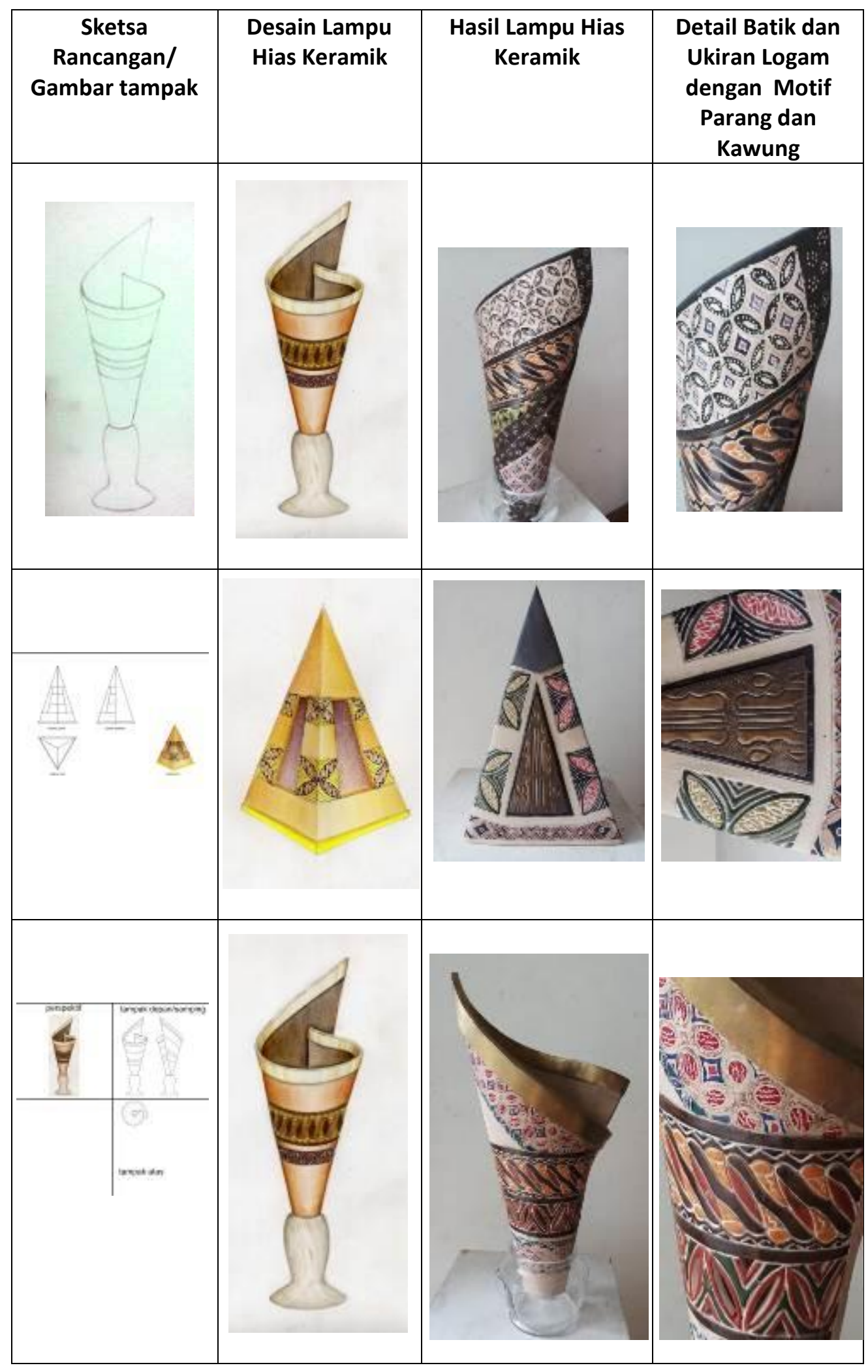




\section{Lampiran 2. Prototype Produk Lampu Hias Keramik}
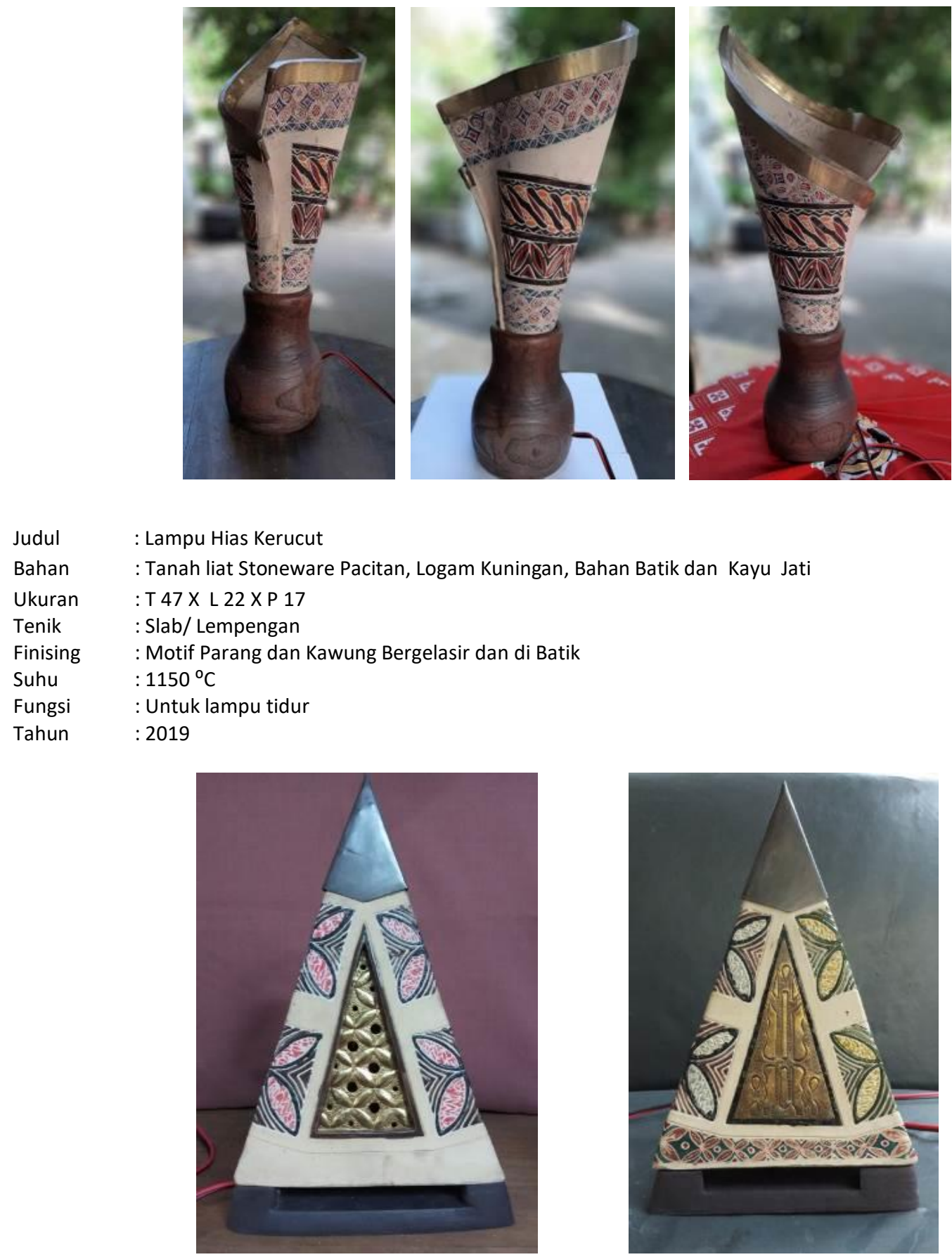

: Tanah liat Stoneware Sukabumi, logam Kuningan dan Multiplek

: Cetak Tuang

: T 36 X L 20 X P 20

Fungsi : Untuk Lampu Tidur 


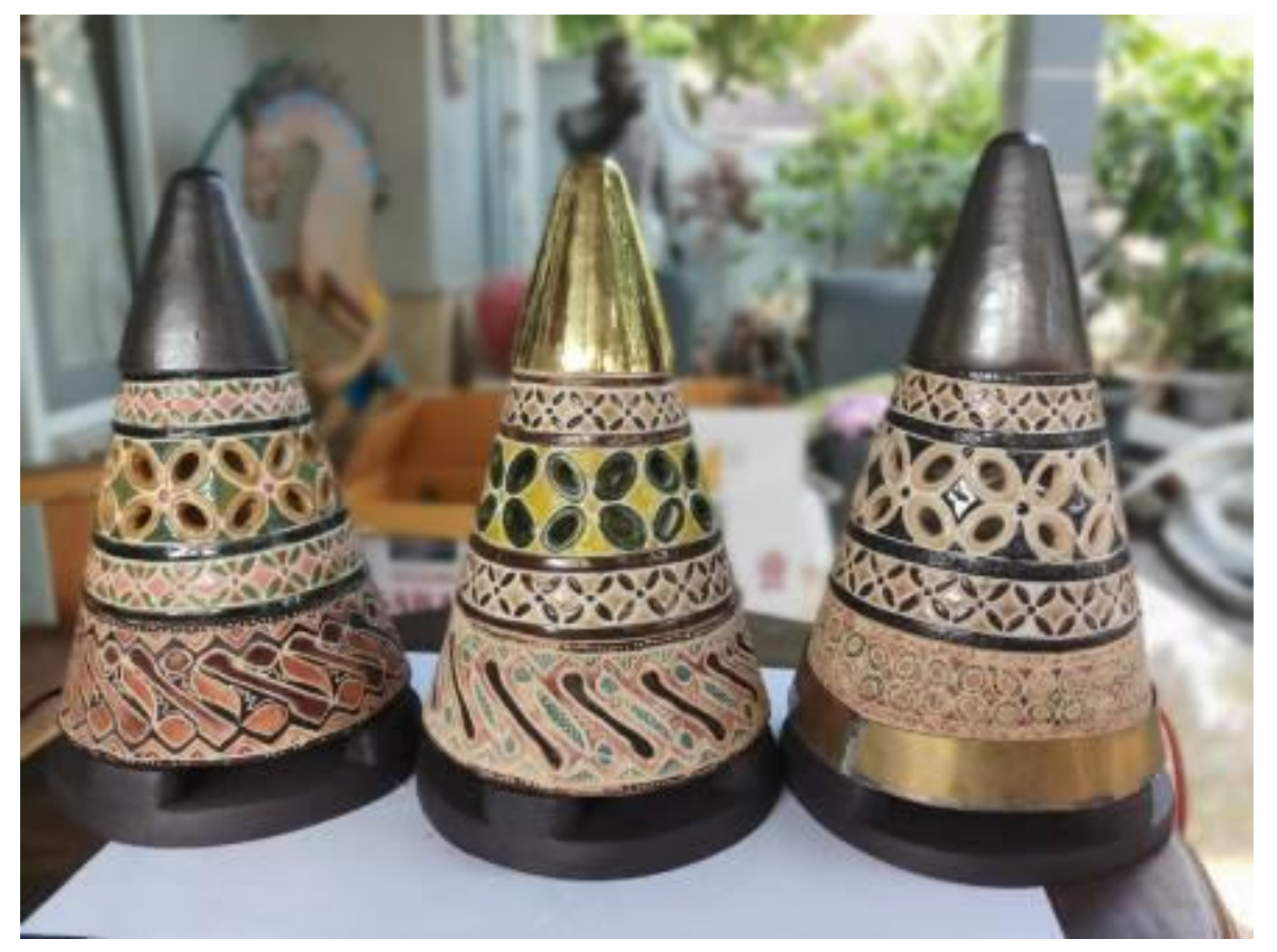

$\begin{array}{ll}\text { Judul } & : \text { Lampu Hias Gunungan } \\ \text { Bahan } & : \text { Tanah liat Stoneware Sukabumi, kayu, logam kuningan dan `bahan batik } \\ \text { Suhu } & : 1150^{\circ} \mathrm{C} \\ \text { Ukuran } & : \text { T. } 32 \times \text { diameter } 19 \mathrm{~cm} \\ \text { Tenik } & : \text { Cetak Tuang } \\ \text { Finising } & : \text { Motif Parang dan Kawung berglasir, ukir logam dan di batik } \\ \text { Fungsi } & : \text { Lampu tidur } \\ \text { Tahun } & : 2019\end{array}$




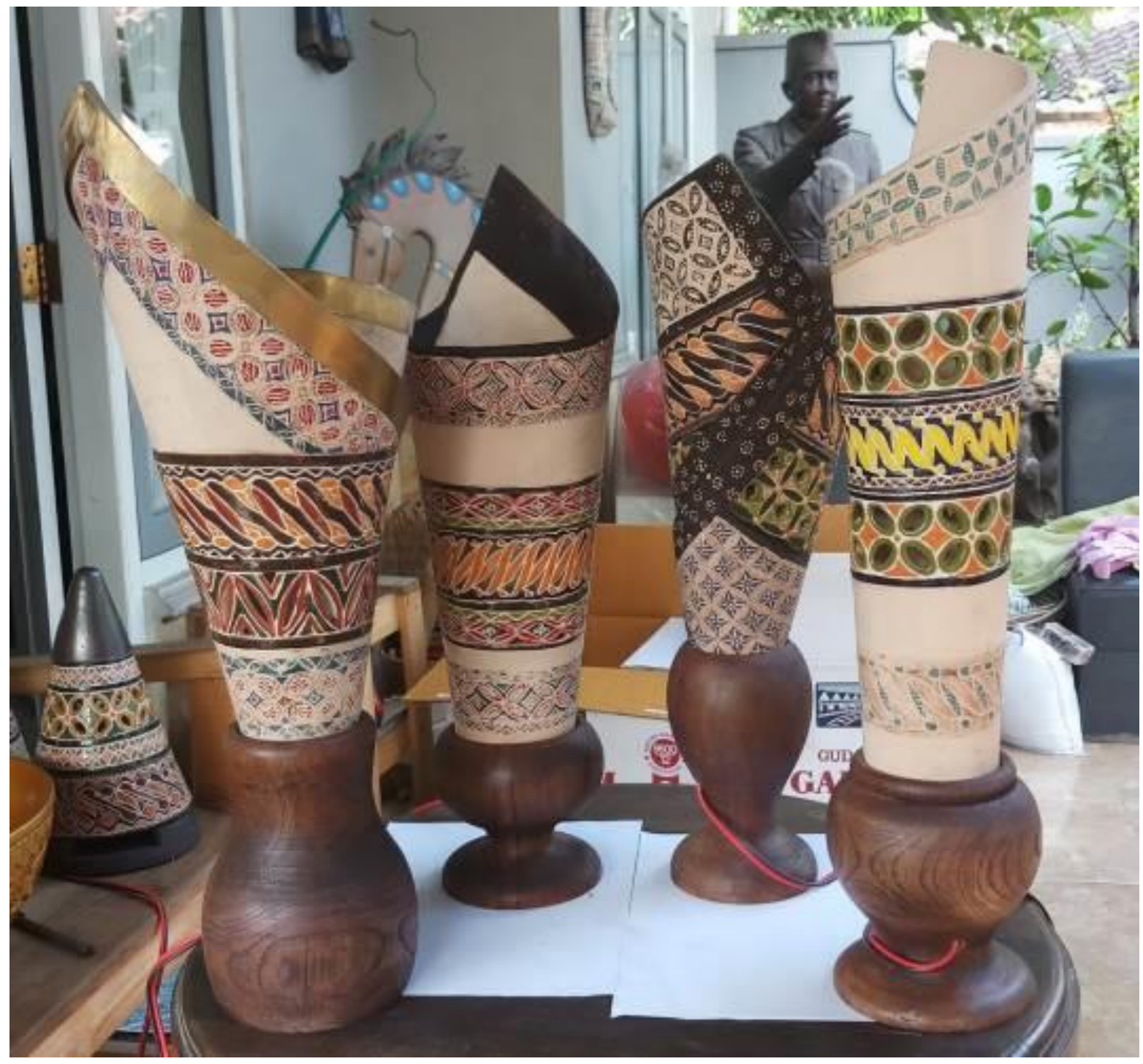

$\begin{array}{ll}\text { Judul } & \text { : Lampu Hias Kerucut } \\ \text { Bahan } & : \text { Tanah liat Stoneware Pacitan, kayu, dan bahan batik } \\ \text { Ukuran } & : \text { T. } 52 \times \text { P. } 18 \times \text { L. } 16 \mathrm{~cm} \\ \text { Tenik } & : \text { Slab / Lempengan } \\ \text { Suhu } & : 1150^{\circ} \mathrm{C} \\ \text { Finisng } & : \text { Motif kawung dan Parang berglasir dan di Batik } \\ \text { Fungsi } & : \text { Lampu Tidur } \\ \text { Tahun } & : 2019\end{array}$




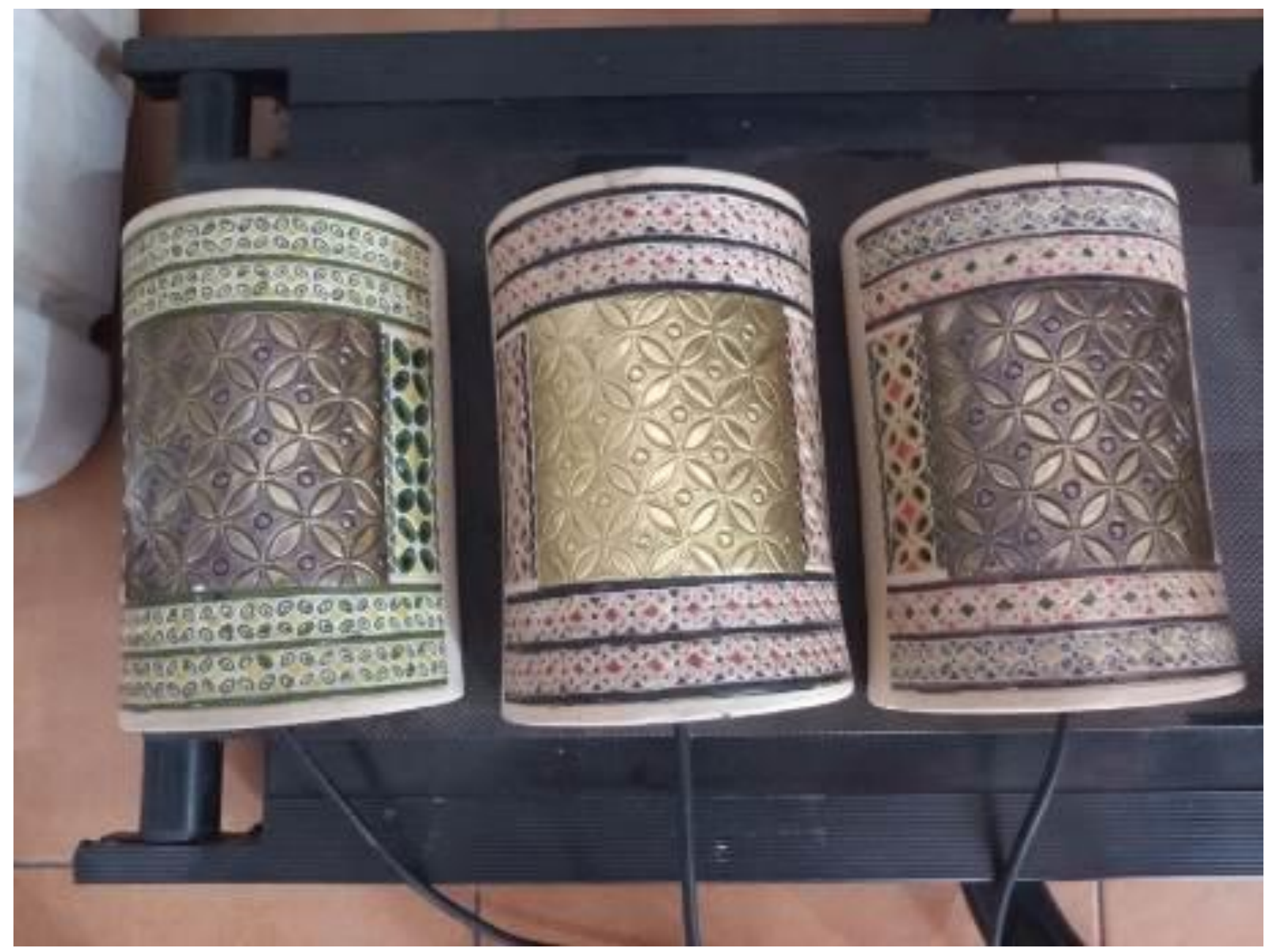
Judul
: Lampu Hias Kawung Setengah Lingkaran
Bahan
: Tanah liat StonewareSukabumi dan Logam Kuningan
Ukuran
: T 26X L 18 X D 10
Finising
Suhu Bakar
: Motif Parang dan Kawung bergelasir dan Ukir Logam
Fungsi
$1150^{\circ} \mathrm{C}$
Tahun
: Untuk Lampu Tidur
: 2019 